\title{
TINJAUAN ASPEK KEAMANAN DAN KERAHASIAN REKAM MEDIS DI RUANG FILING RSBSA BANDUNG
}

\author{
Aloysius F Tarigan ${ }^{1}$, Leni Herfiyanti ${ }^{2}$ \\ Politeknik Piksi Ganesha Bandung, Indonesia ${ }^{1,2}$ \\ Aloysiusfernando97@gmail.com ${ }^{1}$, leniherfiyanti@gmail.com²
}

Received: $14-07-2021$

Revised : 13-11-2021

Accepted: 18-11-2021

\begin{abstract}
Abstrak
Latar Belakang: Keamanan dan kerahasiaan merupakan faktor yang sangat penting dalam pengelolaan dokumen rekam medis. Keamanan dan kerahasian rekam medis di Rumah Sakit Bhayangkara Sartika Asih Bandung masih belum terjaga. Masih ada selain petugas rekam medis yang bisa keluar masuk ke ruang Filing.

Tujuan: Guna mengetahui keamanan dari beberapa segi aspek berkas rekam medis di ruang filing RSBSA Bandung. Metode: Jenis penelitian yang digunakan adalah deskriptif kualitatif dengan menggunakan metode observasi. Objek penelitian yaitu 50 dokumen rekam medis dan ruangan rekam medis.
\end{abstract}

Hasil: Hasil penelitian menunjukkan dari segi aspek fisik tinta yang digunakan berwarna hitam dan kertas yang digunakan berukuran A4. Tidak adanya Out guide, bon peminjaman dan kamper. Selain itu masih ada petugas diluar rekam medis yang bisa keluar masuk dan meminjam dokumen rekam medis tanpa sepengetahuan petugas Filing, sehingga banyak dokumen rekam medis yang hilang atau terbawa oleh petugas. Aspek biologis adanya jamur, serangga seperti rayap, kecoa dan tikus. Aspek kimiawi adanya petugas rekam medis yang makan atau minum di ruang Filing. Aspek kerahasiaanya masih ada dokumen rekam medis yang terbawa atau hilang oleh petugas di luar rekam medis.

Kesimpulan: Berdasarkan hasil penelitian dan pembahasan di atas, penulis menyimpulkan diantaranya untuk menjaga kerahasiaan rekam medis diperlukan ruang Filing yang memenuhi ketentuan dalam menjaga keamanan dan kerahasiaan dokumen rekam medis pasien. Ruang filing dapat dikatakan baik jika telah memenuhi prosedur yang ditentukan dan dapat menjamin keamanan serta terhindar dari kehilangan atau kerusakan yang dapat membahayakan dokumen rekam medis.

Kata kunci: dokumen rekam medis; keamanan; kerahasiaan. 


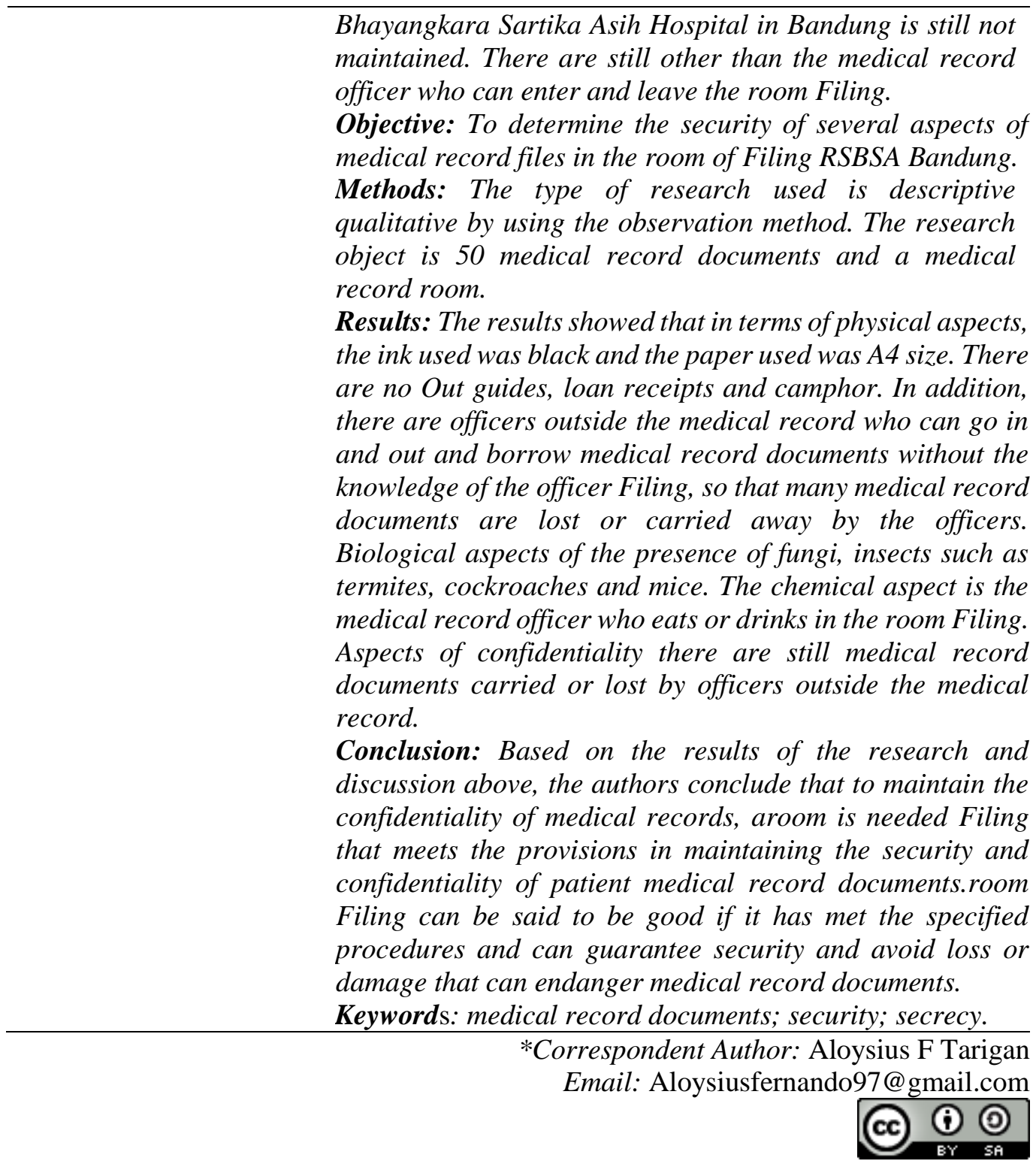

\section{PENDAHULUAN}

Rumah Sakit Bhayangkara Sartika Asih (RSBSA) berawal dari sebuah klinik bersalin (Kraamkliniek) yang didirikan pada tanggal 15 Maret 1957 oleh yayasan kesejahteraan pegawai polisi priangan. Kemudian pada tanggal 21 Mei 1969 berubah menjadi RS. Sartika Asih (RSSA). Pada tanggal 23 Agustus 1999 RSSA berpindah tempat ke Jln. Moch, Toha. No. 369 Bandung. Pada tanggal 30 Oktober 2001 RSBSA disahkan tingkatan statusnya menjadi Rumah Sakit Bhayangkara tingkat II. Berdasarkan Skep Kapolri No. Pol: SKEP/1549/X/2001 tanggal 30 Oktober 2001 berubah nama menjadi Rumah Sakit Bhayangkara Sartika Asih (RSBSA) (Puspita Sari, 2019).

Rekam medis adalah berkas yang berisikan catatan dan dokumen tentang identitas pasien, pemeriksaan, pengobatan, tindakan dan pelayanan lain kepada pasien pada sarana pelayanan kesehatan peraturan Menteri Kesehatan No. 269/MENKES/III/2008 tentang rekam medis, pasal 10 ayat (1) bahwa berkas rekam medis mengandung nilai kerahasiaan yang harus dijaga karena di dalam rekam medis mengandung riwayat pengobatan pasien 
dari awal hingga akhir. Maka dari itu rumah Sakit berkewajiban menjaga keamanan dan kerahasiaan dokumen rekam medis (Permenkes, 2008).

Sistem Filing adalah salah satu bagian dalam unit rekam medis yang berfungsi menyimpan dokumen rekam medis, penyediaan dokumen untuk berbagai keperluan. Perlindungan dokumen rekam medis terhadap kerahasiaan isi data rekam medis, perlindungan dokumen rekam medis terhadap bahaya rusak fisik, kimiawi dan biologi. Sedangkan permenkes No. 269/MENKES/2008 pasal 12 ayat (1) bahwa rekam medis memiliki sarana pelayanan kesehatan, ayat 2 bahwa isi rekam medis merupakan milik pasien, maka Rumah sakit memiliki kewajiban untuk menjaga kerahasiaan dan keawetannya (Menkes, 2008).

Keamanan dokumen rekam medis menyangkut dalam bahaya dan kerusakan rekam medis sendiri. Adapun kerusakan yang meliputi aspek fisik, aspek kimiawi, aspek biologis, serta pencurian. Aspek fisik adalah kerusakan dokumen seperti kualitas kertas dan tinta yang disebabkan oleh sinar matahari, hujan, banjir, panas dan kelembaban. Aspek kimiawi adalah kerusakan dokumen yang disebabkan oleh tikus, kecoa, dan rayap (Hutauruk \& Astuti, 2018). Sedangkan untuk keamanan isi dari dokumen rekam medis perlu adanya ketentuan peminjaman, sehingga dapat diketahui keberadaan dokumen dan siapa peminjamnya, dan juga perlu diketahui juga kepentingan peminjam dokumen harus diperhatikan dari aspek hukumnya (Violita, 2011).

Guna menjaga kerahasiaan rekam medis, diperlukan ruangan Filing yang memenuhi ketentuan dalam menjaga keamanan dan kerahasiaan. Ruang Filing dapat dikatakan baik apabila ruangan tersebut menjamin keamanan dan terhindar dari ancaman kehilangan, kelalaian, bencana dan segala sesuatu yang dapat membahayakan berkas rekam medis tersebut (Siswati \& Dindasari, 2019).

Berdasarkan hasil observasi dan wawancara di Rumah Sakit Bhayangkara Sartika Asih Bandung, keamanan dan kerahasiaan berkas rekam medis di ruang Filing belum terlalu baik. Peneliti menemukan beberapa masalah yang berkaitan dengan keamanan dan kerahasiaan rekam medis. Terdapat 3 ruangan penyimpanan rekam medis yang terpisah, keadaan ini mengakibatkan petugas rekam medis kesulitan untuk melakukan pengawasan. Peneliti juga sering menemukan beberapa dokumen rekam medis yang robek dan terlipat karena rak penyimpanan yang sudah sangat padat.

Menurut data yang peneliti dapatkan pada bulan April - Mei tahun 2021 ada 4 dokumen rekam medis yang hilang karena di bawa atau di pinjam oleh petugas rumah sakit tanpa seizin petugas Filing. Sering di dapat juga petugas rumah sakit yang tidak termasuk bagian Filing mendistribusikan dokumen rekam medis. Padahal setiap pintu ruangan ruangan rekam medis baik ruang Filing atau ruang kerja sudah terdapat tanda peringatan bahwa selain petugas dilarang masuk. Hal ini sejalan dengan teori (Salsabila, 2017) bahwa ruang Filing harus aman (untuk melindungi dokumen rekam medis dari kerusakan, kehilangan, atau digunakan oleh pihak tidak berwenang). Berdasarkan permasalahan tersebut, peneliti ingin membahas "Tinjauan Aspek Keamanan Dan Kerahasiaan Rekam Medis di Ruang Filing RSBSA Bandung”.

\section{METODE PENELITIAN}

Penelitian ini menggunakan metode kualitatif dengan menggunakan pendekatan deskriptif melalui observasi dan wawancara. Metode observasi yaitu metode penelitian dengan meninjau langsung objek yang diteliti (Notoamodjo, 2018). Penelitian ini di mulai pada bulan April - Mei 2021. Dilakukan di Rumah Sakit Bhayangkara Sartika Asih Bandung. Populasi dalam penelitian ini adalah dokumen rekam medis yang ada di ruang Filing Rumah Sakit Bhayangkara Sartika Asih Bandung pada bulan April - Mei 2021 bertambah sebanyak 256 dokumen rekam medis pasien baru.

Tinjauan Aspek Keamanan dan Kerahasian Rekam Medis di Ruang Filing RSBSA Bandung 
Data primer di peroleh langsung dari petugas rekam medis dari sumber observasi dan aspek - aspek keamanan dan kerahasiaan dokumen rekam medis (Sari, 2011). Data sekunder adalah data yang sudah ada yaitu kebijakan prosedur atau Standar Operasional Prosedure (SOP) di Rumah Sakit Bhayangkara Sartika Asih Bandung (Huffman, 1994).

\section{HASIL DAN PEMBAHASAN}

\section{A. Hasil Penelitian}

Tabel 1. Aspek Fisik

\begin{tabular}{ccc}
\hline No & Jenis Kertas & Tinta \\
\hline 1 & A4 70gr & Hitam \\
\hline
\end{tabular}

Berdasarkan tabel 1 di atas, hasil observasi yang dilakukan di Rumah Sakit Bhayangkara Sartika Asih Bandung kualitas kertas dan tinta yang digunakan untuk formulir sudah sangat baik. Namun kualitas untuk map belum menggunakan map yang berkualitas baik.

\section{Fasilitas Ruangan}

Tabel 2. Fasilitas Ruangan Mempengaruhi Keamanan Dokumen Rekam Medis Di Ruang Filing RSBSA Bandung

\begin{tabular}{clcc}
\hline No & Fasilitas Ruangan & Ada & Tidak ada \\
\hline 1 & AC & $\checkmark$ & \\
\hline 2 & Roll o pack & $\checkmark$ & \\
\hline 3 & Out Guide & & \\
\hline 4 & Alat Pengukur kelembaban Suhu & $\checkmark$ & \\
\hline 5 & APAR & $\checkmark$ & $\checkmark$ \\
\hline 6 & Kamper & & $\checkmark$ \\
\hline
\end{tabular}

Berdasarkan dari tabel 2 di atas dapat dilihat bahwa fasilitas ruangan rekam medis mempengaruhi keamanan dan keawetan dokumen rekam medis, yaitu tidak adanya Out guide, alat pengukur kelembaban suhu dan kamper.

\section{Kondisi Ruangan}

Tabel 3. Kondisi Ruangan Mempengaruhi Keamanan Dokumen Rekam Medis Di RSBSA Bandung

\begin{tabular}{lccc}
\hline No & Kondisi Ruangan & Ada & Tidak ada \\
\hline 1 & Atap Bocor & & $\checkmark$ \\
\hline 2 & Pencahayaan & $\checkmark$ & \\
\hline
\end{tabular}

Berdasarkan tabel 3 di atas dapat dilihat bahwa kondisi ruangan medis mempengaruhi keamanan dokumen rekam medis yaitu adanya pencahayaan sinar matahari yang langsung jatuh di permukaan dokumen rekam medis.

\section{Kelembaban Suhu}

Tabel 4. kelembaban Suhu Mempengaruhi Keamanan Dokumen Rekam Medis di Ruang Filing

Tinjauan Aspek Keamanan dan Kerahasian Rekam Medis di Ruang Filing RSBSA Bandung 


\begin{tabular}{ccc}
\hline No & Waktu & Suhu \\
\hline 1 & Pengukuran I Selasa, 13 April 2021 & $31,5^{\circ} \mathrm{C}$ \\
\hline 2 & Pengukuran II Rabu, 14 April 2021 & $21,7^{\circ} \mathrm{C}$ \\
\hline 3 & Pengukuran III Kamis, 15 April 2021 & $21,3^{\circ} \mathrm{C}$ \\
\hline
\end{tabular}

Berdasarkan dari tabel 4 di atas dapat dilihat bahwa pengukuran kelembaban suhu yang dilakukan selama 3 kali terdapat perubahan di hari ke 2 dan 3 di mana suhunya $21,7^{\circ} \mathrm{C}$ dan $21,3^{\circ} \mathrm{C}$ suhu normal.

\section{Aspek Biologis}

Tabel 5. Organisme Yang Dapat Mempengaruhi Keamanan Dokumen Rekam

\begin{tabular}{clcc}
\hline No & Organisme yang merusak dokumen & Ada & Tidak Ada \\
\hline 1 & Jamur & & $\checkmark$ \\
\hline 2 & Kutu Buku & & $\checkmark$ \\
\hline 3 & Serangga (rayap, kecoa, dan tikus) & $\checkmark$ & \\
\hline
\end{tabular}

Berdasarkan tabel 5 di atas dapat dilihat bahwa masih ada jamur dan serangga yang terlihat di ruang Filing.

\section{Aspek Kimiawi}

Tabel 6. Bahan-Bahan Kimia Mempengaruhi Keamanan Dokumen Rekam Medis di Ruang Filing RSBSA Bandung

\begin{tabular}{cccc}
\hline No & Ancaman & Ada & Tidak Ada \\
\hline 1 & Makanan/Minuman & $\checkmark$ & \\
\hline 2 & Debu & $\checkmark$ & \\
\hline
\end{tabular}

Berdasarkan tabel 6 di atas dapat dilihat bahwa makanan/minuman dan debu mempengaruhi keamanan dan keawetan dokumen rekam medis.

\section{Aspek Kerahasiaan Dokumen Rekam Medis di Ruang Filing}

Tabel 7. Kerahasiaan Dokumen Rekam Medis

\begin{tabular}{cccc}
\hline No & Ancaman & Ada & Tidak Ada \\
\hline 1 & Selain petugas Filing yang masuk ke ruang penyimpanan & & $\checkmark$ \\
\hline 2 & Dokumen rekam medis yang dibawa pasien atau hilang & $\checkmark$ & \\
\hline 3 & Dokter dan perawat wajib menjaga isi rekam medis & $\checkmark$ & \\
\hline
\end{tabular}

Berdasarkan tabel 7 di atas dapat dilihat bahwa dokter dan perawat menjaga kerahasiaan isi rekam medis, tidak menjadi penyebab kerahasiaan dokumen rekam medis, melainkan ada selain petugas rekam medis yang masuk ke ruang penyimpanan dan ada dokumen yang terbawa atau hilang.

\section{B. Pembahasan}

\section{Aspek Fisik}

Berdasarkan hasil observasi yang dilakukan di Rumah Sakit Bhayangkara Sartika Asih Bandung, ditemukan bahwa kualitas kertas dan tinta yang digunakan sudah baik. Namun bahan perekat map mudah lepas dan mudah robek sehingga formulir mudah lepas dari map. Kerusakan arsip berasal dari bahan arsip itu sendiri, kualitas kertas, tinta, dan lem perekat sangat mempengaruhi kualitas arsip. Arsip mengandung bahan kimia sehingga 
proses kerusakannya dapat terjadi cepat atau lambat tergantung kualitas bahan yang digunakan. Hasil penelitian ini berupa desain yang diharapkan dapat digunakan untuk bahan pertimbangan di dalam merencanakan suatu formulir khususnya formulir surveilans infeksi, sehingga rumah sakit lebih mudah di dalam melakukan kegiatan pencatatan dan pelaporan mengenai surveilans infeksi nosokomial.

\section{Aspek Kimiawi}

Aspek kimiawi adalah kerusakan dokumen yang disebabkan oleh makanan, minuman, dan bahan-bahan kimia (Rohmawati, Supriadi, \& Wahab, 2021). Berdasarkan hasil observasi yang dilakukan di Rumah Sakit Bhayangkara Sartika Asih Bandung, aspek kimiawi terjadi karena kualitas bahan yang digunakan kurang baik, karena penggunaan bahan yang kurang berkualitas akan merusak dan luntur dengan sangat mudah. Terkadang ada petugas yang membawa makanan atau minuman keruang Filing apabila makanan mengandung minyak dapat mengotori ruangan yang dapat mengakibatkan dokumen akan mudah rusak.

\section{Aspek Kerahasiaan Dokumen Rekam Medis}

Berdasarkan hasil penelitian masih banyak terdapat selain petugas rekam medis yang keluar masuk ruang Filing membawa dokumen rekam medis tanpa persetujuan petugas Filing. Rekam medis bersifat sangat rahasia karena terdapat identitas, diagnosis, riwayat penyakit, riwayat pemeriksaan dan riwayat pengobatan milik pasien (Rahmadiliyani \& Faizal, 2018). Bab IV butir 2 keputusan DIRJEN Pelayanan Medik Nomor: 78/Yanmed/RS.UM.DIK/YMU/I/91 tentang petunjuk pelaksanaan penyelenggaraan Rekam Medik/Medical Record di rumah sakit, yang berbunyi (isi rekam medis adalah milik pasien yang wajib dijaga kerahasiaannya) (Ri, 2006). Guna melindungi kerahasiaannya tersebut, maka dibuat ketentuan diantaranya hanya petugas rekam medis yang diizinkan masuk kedalam kedalam penyimpanan berkas rekam medis, dilarang mengutip sebagian atau seluruh isi rekam medis untuk badan-badan atau perorangan, kecuali yang telah ditentukan oleh peraturan perundang-undangan yang berlaku, Selama pasien dirawat, rekam medis menjadi tanggung jawab perawat ruangan dan menjaga kerahasiaannya (Firdaus, 2008).

\section{KESIMPULAN}

Berdasarkan hasil penelitian dan pembahasan di atas, penulis menyimpulkan diantaranya untuk menjaga kerahasiaan rekam medis diperlukan ruang Filing yang memenuhi ketentuan dalam menjaga keamanan dan kerahasiaan dokumen rekam medis pasien (Putri, 2011).

Namun dalam penelitian (Ohoiwutun \& Setiatin, 2021), bahwa unit kerja Rekam Medis yang diakreditasi oleh Departemen Kesehatan yang berfungsi sebagai tempat pengaturan dan penyimpanan dokumen atas dasar sistem penataan tertentu melalui prosedur yang sistematis sehingga sewaktu-waktu dibutuhkan dapat menyajikan secara cepat dan tepat. Ruang Filing dapat dikatakan baik jika telah memenuhi prosedur yang ditentukan dan dapat menjamin keamanan dan terhindar dari kehilangan atau kerusakan yang dapat membahayakan dokumen rekam medis. Ruang Filing belum menjamin keamanan dan kerahasiaan rekam medis dikarenakan semua petugas mengetahui kode kunci pintu ruang Filing. Sehingga petugas yang bukan bagian dari Filing dapat dengan mudah keluar masuk dan mengambil berkas lalu mendistribusikan tanpa izin petugas Filing. 


\section{BIBLIOGRAFI}

Firdaus, Sunny Ummul, Kirana, Rosita Cadra, Siswantiti, Nurulla Tri, \& Saddhono, Kundharu. (2008). Rekam medik dalam sorotan hukum dan etika. Lembaga Pengembangan Pendidikan (LPP).

Huffman, Edna K. (1994). Health information management.

Hutauruk, Puput Melati, \& Astuti, Widya Tri. (2018). Tinjauan Aspek Keamanan dan Kerahasiaan Dokumen Rekam Medis Di Ruang Filing Rumah Sakit Khusus (RSK) Paru Medan Tahun 2018. Jurnal Ilmiah Perekam Dan Informasi Kesehatan Imelda (JIPIKI), 3(2), 510-517.

Menkes, R. I. (2008). Peraturan Menteri Kesehatan Republik Indonesia No. 269/MenKes/Per/III/2008 tentang Rekam Medis. Jakarta: Kementerian Kesehatan $R I$.

Notoamodjo Soekidjo. (2018). Metodologi Penelitian Kesehatan. Jakarta: PT. Rineka Cipta.

Ohoiwutun, Norberta, \& Setiatin, Sali Setiatin. (2021). Pengaruh Latarbelakang Pendidikan Perekam Medis Terhadap Sistem Penyimpanan Rekam Medis di RSUD Boven Digoel. Cerdika: Jurnal Ilmiah Indonesia, 1(8), 1029-1036.

Permenkes. (2008). Peraturan Menteri Kesehatan No.269/MENKES/PER/III/2008.

Puspita Sari, Rika. (2019). Analisis Efektivitas Biaya Pengobatan Pneumonia Anak Menggunakan Ampisilin-Sulbaktam Dan Seftriakson Di Rumah Sakit Bhayangkara Sartika Asih Bandung.

Putri, Novi Mulyani. (2011). Hubungan Beban Kerja Coder dengan Keakuratan Kode Diagnosis Pasien Rawat Inap Berdasarkan ICD-10 di RSUP dr. Sardjito Yogyakarta Tahun 2011. Universitas Muhammadiyah Surakarta.

Rahmadiliyani, Nina, \& Faizal, Faizal. (2018). Kerahasiaan Rekam Medis Di Rumah Sakit Aveciena Medika Martapura. Jurnal Manajemen Informasi Kesehatan Indonesia (JMIKI), 6(2), 69-78.

Ri, Depkes. (2006). Pedoman Penyelenggaraan dan Prosedur Rekam Medis Rumah Sakit di Indonesia. Jakarta: Depkes RI.

Rohmawati, Ade, Supriadi, Tasya Saldira Putri, \& Wahab, Syaikhul. (2021). Tinjauan Pelaksanaan Assembling Dalam Pengendalian Ketidaklengkapan Dokumen Rekam Medis Rawat Inap di RSUD Soreang. Cerdika: Jurnal Ilmiah Indonesia, 1(9), 10791086.

Salsabila, Luthfi Nisrina. (2017). Tinjauan Aspek Keamanan Berkas Rekam Medis di RSUD Wates Kulon Progo.

Sari, Tri Kartika. (2011). Analisis Faktor Penyebab Ketidaklengkapan Rekam Medis Rawat Inap RSU Haji Surabaya. UNIVERSITAS AIRLANGGA.

Siswati, Siswati, \& Dindasari, Dea Ayu. (2019). Tinjauan Aspek Keamanan dan Kerahasiaan Rekam Medis di Rumah Sakit Setia Mitra Jakarta Selatan. Jurnal Rekam Medis Dan Informasi Kesehatan, 2(2), 91-99.

Violita, Desima. (2011). Pengelolaan Arsip di Bagian Sekretariat Rumah Sakit PKU Muhammadiyah Surakarta.

(C) 2021 by the authors. Submitted for possible open access publication under the terms and conditions of the Creative Commons Attribution (CC BY SA) license (https://creativecommons.org/licenses/by-sa/4.0/). 